\title{
Introduction
}

\section{REGIONAL SETTING}

The White-Inyo Range is approximately $110 \mathrm{mi}(178 \mathrm{~km})$ long and consists of mountains that rise from valleys to the east and west. The range is located at the interface of two major physiographic provinces: the Pacific-influenced Sierra-Nevada

Cascade Province and the arid Basin and Range Province. The mountains at the lower elevations, near $4,000 \mathrm{ft}(1,220 \mathrm{~m})$, are dotted with Great Basin Sage, and the mountains rise to elevations of more than $14,000 \mathrm{ft}(4,400 \mathrm{~m})$ and the Alpine Steppe. The rise is an abrupt one, occurring sharply over a $12 \mathrm{mi}(20 \mathrm{~km})$ linear distance. There is close proximity to the Sierra Nevada to the west, but there are closer biologic ties with the plants and animals of the Basin and Range Province.

The White-Inyo Range expresses moderate geologic diversity (e.g., granitic rocks, basalt, metavolcanic rocks, and weakly to moderately metamorphosed sandstone, shale, limestone, and dolomite) and great topographic diversity. The range consists of complexly folded and faulted rocks, some more than 600 million years old, that lie in a triangular, fault-bounded block. The block rises abruptly on the west above the active White Mountain fault zone fronting the range, along which occurred the 1986 Chalfant Valley Earthquake. The block is more gently inclined to the east. The presence of different types of rock results in striking constrasts in landscape color and form, and the gentle rolling topography of parts of the crest of the range contrasts sharply with the steeply inclined and deeply dissected slopes.

The climate of the range is characterized by cold, dry weather. The average maximum-minimum temperature ranges are from $\sim 70^{\circ} \mathrm{F}\left(21^{\circ} \mathrm{C}\right)$ to $37^{\circ} \mathrm{F}\left(\sim 3^{\circ} \mathrm{C}\right)$, at the base of the range near Bishop, and from $36^{\circ} \mathrm{F}\left(2^{\circ} \mathrm{C}\right)$ to $-26^{\circ} \mathrm{F}\left(-32^{\circ} \mathrm{C}\right)$ recorded at the Barcroft facilities of the White Mountain Research Station in the Alpine Zone. Precipitation averages from 4 in $(10 \mathrm{~cm})$ at the base of the range to 20 in $(50 \mathrm{~cm})$, largely as snow, along its crest. Local variation in precipitation and runoff is strongly influenced by topography. The winds at the crest of the range are persistent and frequently strong during both summer and winter. Thunder and lightning storms can be hazardous to hikers in the high country, and a hike to White Mountain Peak in a thunderstorm is strongly discouraged.

Soil quality is poor in the White-Inyo Range, and soil development is slowest in the alpine zones. The White-Inyo Range, with its high elevation and special climate, is a rare and fragile environment. Rapid changes in elevation are associated with abrupt changes in habitats and species, which enhances the area as a scientific research region. The short growing season results in limited plant productivity in a given year. As a result of the thin soil and sparse and delicate vegetation, recovery from disturbance is very slow, estimated to be more than 100 years; thus, this is an area demanding diligent preservation. 


\section{MODERN MAN IN THE WHITE MOUNTAINS}

Livestock was introduced into the Owens Valley in 1861, and prospectors were working on the east side of the White Mountains the same year. There were hostilities between native Americans and American settlers during the years from 1862 to 1865 . As a consequence, many immigrants and native Americans were killed, and, ultimately, more than 800 native Americans were force-marched hundreds of miles to Fort Tejon, south of Bakersfield. The stirring and interesting accounts of the history of the region by Willie Arthur Chalfant (1933, reprinted 1980) provide sobering reminders of the immoral behavior of the early settlers of the region. Little is known about the early ranching of the area, principally during the 1870 s, except that at one time more than 40,000 sheep overgrazed the high meadows and plateaus of what is now the Inyo National Forest. In 1907 grazing regulations were established, and hostilities occurred, this time between angry ranchers and the U.S. Forest Service; and in 1909 the Army was called in to quell the range war. It was not until 1931 that the U.S. Forest Service achieved full control of the White Mountains. Only limited portions of the crest zone are satisfactory or usable livestock range today; however, eight range allotments currently divide the entire White Mountains among four active cattle ranches. The allotments carry only a few to approximately 300 head. The presence of livestock in the sensitive alpine zones is in conflict with those interested in the preservation of the fragile environment and scientific research.

In 1948 the U.S. Navy sought a location to test infrared sensors and chose a site at Crooked Creek; in 1949 an installation was erected. In 1950 the U.S. Navy authorized the University of California to operate the Crooked Creek facilities as a research center, and in 1978 the Navy transferred title of all facilities and equipment to the University of California's White Mountain Research Station.

White Mountain Research Station, with its principal office located in the Owens Valley near Bishop, was established in 1950 to provide laboratory facilities for any qualified research investigator wishing to utilize the high-mountain environment for his or her work, and to serve as teaching facilities for field courses conducted in the region. There are four separate laboratory sites: one in the Owens Valley; a second at Crooked Creek, at an elevation of approximately $10,000 \mathrm{ft}(2,090 \mathrm{~m})$; a third at the base of $\mathrm{Mt}$. Barcroft, at an approximate elevation of $12,500 \mathrm{ft}(3,801 \mathrm{~m})$, making it the 11th highest high-altitude station in the world and the fourth highest in North America; and a fourth, the Summit Laboratory, atop White Mountain Peak, at an elevation of $14,246 \mathrm{ft}(4,340 \mathrm{~m})$. The Summit Laboratory is the fourth highest high-altitude research facility in the world and the highest in North America.

The establishment of the University of Californias facilities in the area marked the beginning of two independent lines of scientific interest: (1) astronomy and astrophysics, with a need for observatory sites that could provide the best infrared telescopic seeing conditions and a minimum of atmospheric interference; and (2) biology, with the need for protection from harsh climatic conditions while studies of the ecology of the high-altitude environment and physiological processes related to reduced oxygen levels at high elevations are under way. These types of work continue 
today and have been augmented by other studies, such as geology, geomorphology, archaeology, dendrochronology, and a wealth of biologic studies that include predator/prey relationships, dietary studies, the cardiovascular system, speciation, plant genetics, and metabolism, among many others. Since 1950, over 750 technical papers, books, and theses have been published by those associated with White Mountain Research Station.

The panoramic views of the Sierra Nevada and the Ancient Bristlecone Pine Forest are the principal attractions for tourists, and recreational use of the White-Inyo Range is light because of lack of water. Camping is limited to the U.S. Forest Service's Grandview Campground, which is a dry camp and is thus only used by watercarrying visitors. Recreational pressures will probably continue to increase, however, and this will surely affect the White Mountains and may conflict with the concept of a wilderness area to preserve the fragile lands and animals, such as the White Mountain Bighorn Sheep. The interests of man - grazing, mining, scientific research, the local economy, preservation of endangered species, and recreation in the White Mountains - will doubtless be in conflict and represent sensitive issues; these will continue to require careful study.

The interested visitor may wish to learn more about the region and is directed to the following sources (see also references at the ends of chapters):

Cain, Ella M. 1961. The story of early Mono County, its settlers, gold rushes, Indians, ghost towns. Fearon Publishers, San Francisco (out of print).

Chalfant, Willie Arthur. 1933 (reprinted and revised 1980). The story of Inyo, Chalfant Press, Bishop.

Leadabrand, Russ. 1973. Exploring California byways. VI. Owens Valley: Trips for a day or a week. Ward Ritchie Press, Los Angeles.

Lloyd, Robert M. and Richard S. Mitchell. 1973. A flora of the White Mountains, California and Nevada. University of California Press, Berkeley.

Rinehart, Dean, Elden Vestal, Bettie E. Willard, edited by Genny Smith. 1989. Mammoth Lakes Sierra: A bandbook for radside and trail. Genny Smith Books, Mammoth Lakes.

Schumacher, Genny. 1969. Deepest valley: Guide to Owens Valley and its mountains, lakes, radsides and trails. Wilderness Press, Berkeley (out of print, but a new edition is planned by Genny Schumacher Smith). 
